\title{
Wound Healing Activity of Gel Formulated Leaves Extract of Neolamarckia cadamba (Roxb) Bosser
}

\author{
Shruti Nayan, Chanchal Kumar Mishra, Divya Priyadarshini, Kishanta Kumar Pradhan, Manik Ghosh, \\ Ashok Pattnaik*
}

Department of Pharmaceutical Sciences and Technology, Birla Institute of Technology, Mesra, Jharkhand, INDIA.

\begin{abstract}
Background: Wound occurs when integrity of the skin is compromised. Healing of wounds occur in various phases namely hemostasis, inflammation, proliferation, granulation, contracture remodelling. Neolamarckia cadamba leaves had been used by the tribal people for the treatment of wounds. Objectives: To formulate a gel of Neolamarckia cadamba which contains carbopol 934 as a gelling agent and to determine its wound healing activity by topical application of gel of Neolamarckia cadamba on surgically induced wounds in Swiss albino mice. Materials and Methods: To study the wound healing properties, free radical scavenging activity by DPPH, nitric oxide, total phenolic content estimation, antibacterial activity, excision and incision studies and histopathology were done. Ethyl acetate fraction of methanolic leaves extract of Neolamarckia cadamba (EAFNC) was applied topically as a $2 \%$ gel. Percentage of wound contraction and tensile strength was determined in excision and incision wound model respectively. Results: The animals treated with EAFNC showed significant percentage inhibition of nitric oxide and DPPH as compared to ascorbic acid. Antibacterial activity of EAFNC against Bacillus subtilis and Pseudomonas aeruginosa was also seen. Also, there was increase in wound contraction on $12^{\text {th }}$ post wounding day $(81.33 \pm 0.574)$, tensile strength (4.645 \pm 0.1345$)$. Histopathology of regenerated skin of EAFNC showed prominent collagen networks, mononuclear cells and fibroblasts. Conclusion: The ethyl acetate fraction of methanolic leaves extract of Neolamarckia cadamba (EAFNC) showed significant increase in wound healing activity validating its use by the tribal people.
\end{abstract}

Key words: Neolamarckia cadamba, Wound Healing, Excision, Incision, Megaheal gel.

\section{INTRODUCTION}

Skin acts as a barrier to different chemicals, dust, water and various diseases causing by micro-organisms. This barrier is destroyed because of injury or wound. A wound occurs when integrity of the skin is compromised. It may occur due to fall, surgery, infection, some underlying conditions or disease. Wound heals in different phases namely hemostasis, inflammation, proliferation, granulation, contracture remodelling. The main purpose behind wound management is to heal the wound in shortest time as possible with minimal discomfort, suffering and pain. ${ }^{1-3}$

In India medicines based on herbal origin has been the basis of treatment and cure of various diseases. So, a large number of plants species are used for this purpose. Among all those plants, one such plants is Neolamarckia cadamba and it belongs to the family Rubiaceae. ${ }^{4,5}$ It is very much common in West Bengal, Odisha, Andhra Pradesh, Karnataka and Kerala. ${ }^{6}$ This plant is reported to have pent-acyclic triterpinic acid, quinovic acid, beta-sitosterol, indole alkaloids, triterpenoid, saponin etc. ${ }^{7-9}$ In Ayurveda bark is used for blood related disease. In traditional Indian medicine, bark and roots are used for fevers, colic, muscular pain, stomach burning, poisoning, gynecologoical problems cough edema as well as it also possess aphrodisiacs activity.
Submission Date: 05-04-2019; Revision Date: 24-05-2019; Accepted Date: 09-07-2019

DOI: 10.5530/ijper.53.3s.114 Correspondence: Dr. Ashok Pattnaik, Associate Professor, Department of Pharmaceutical Sciences and Technology, Birla Institute of Technology, Mesra, Ranchi-835215, Jharkhand, INDIA. Phone: +91-6512276247 E-mail: ashokpattnaik8@ gmail.com

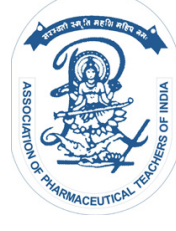

www.ijper.org 
Fresh leaves are used to treat jaundice, ulcers and to alleviate pain. Bark paste applied externally for muscular pains and its decoction used for fevers. Powdered bark are boiled with fruits and inhaled through the mouth in order to treat toothache. The leaves of this plant is used traditionally for wound healing purpose. ${ }^{6}$

Although this plant has been used traditionally by the tribal people, but it has not been scientifically validated so far and no scientific report is available regarding the wound healing activity of plant leaves of Neolamarckia cadamba to the best of our knowledge.

So, the present study was aimed to explore the wound healing potential of leaves of Neolamarckia cadamba using incision and excision wound models.

\section{MATERIALS AND METHODS}

\section{Plant materials}

Neolamarckia cadamba were collected from the campus of Birla Institute of Technology, Mesra, Ranchi, Jharkhand and the plant was authenticated from Central National Herbarium, Botanical Survey of India, Botanical Garden, Howrah [Herbarium No.: CNH/ Tech. II/ 2015/ 66].

\section{Experimental Animals}

Swiss albino mice were used in the study. Animal were procured from Laboratory Animal House, Department of Pharmaceutical Science and Technology (Birla Institute of Technology, Mesra). All animal experiments are strictly complied with approval of Institutional Animal Ethical Committee (Protocol No.: PROV/BIT/PH/ IAEC/19/2015).

\section{Chemicals}

All the chemicals were used for analytical grade. Silica gel G (Merck, Darmstadt, Germany), Pet ether, chloroform, DPPH, Quercetin, Carbopol 934, ethyl acetate, methanol.

\section{Preparation of Plant extract ${ }^{10,11}$}

Leaves of the plant were dried and subjected to size reduction in powder form. The powdered plant material was extracted by cold maceration using petroleum-ether (60-80), chloroform and methanol. Extract obtained was decanted and clarified by filtration, concentrated in a rotary evaporator. Methanolic leaves extract of Neolamarckia cadamba was showing better presence of Phytochemical and used in the following experiment.

Separation and fractionation of the methanolic leaves extract was done by separating funnel method and com- pound fraction was isolated using TLC and ethyl acetate fraction were used.

\section{Preparation of gel ${ }^{12-15}$}

For preparation of EAFNC gel, Carbopol 934 (1.0\%), Methyl paraben $(0.5 \%)$, propyl paraben $(0.2 \%)$, triethanolamine $(1.2 \%)$, Distilled water $(100 \%)$ and propylene glycol $400(2.5 \%)$ was used. In order to prepare a gel, Carbopol 934 was dispersed in $50 \mathrm{ml}$ of distilled water with continuous stirring. $2 \mathrm{ml}$ of distilled water was mixed with methyl paraben and propyl paraben and dissolved by heating on a water bath with continuous stirring. Solution was cooled and propylene glycol 400 was added to form a gel. EAFNC was mixed with distilled water to make a volume up to $100 \mathrm{ml}$. Small amount of triethanolamine was added to maintain the $\mathrm{pH}$ of the gel formulation.

\section{In vitro studies}

\section{Free radical scavenging assay by $D P P H^{16}$}

After the preparation of the stock solution of ascorbic acid, it was diluted with methanol. An aliquot of each dilution was mixed with methanolic solution of DPPH. The mixtures were incubated at $37^{\circ} \mathrm{C}$ in dark for $30 \mathrm{~min}$ after shaking vigorously. At the same time a control containing methanolic solution of DPPH was run. The absorbance was measured at $517 \mathrm{~nm}$ against methanol as blank. The percentage of DPPH scavenging was calculated as follows:

Scavenging activity $(\%)=\frac{(\text { Control absorbance }- \text { EAFNC absorbance })}{\text { Control absorbance }} \times 100$

\section{Nitric oxide radical scavenging assay ${ }^{17}$}

Sodium nitroprusside in phosphate buffered saline was mixed with different concentrations of methanol and incubated at $37^{\circ} \mathrm{C}$ for $2 \mathrm{~h}$. The same reaction mixture without the extract but the equivalent amount of ethanol served as the control. After the incubation period, $0.5 \mathrm{ml}$ of Griess reagent was added. The absorbance was read at $550 \mathrm{~nm}$. The percentage of nitric oxide radical scavenging of both EAFNC and standard compound was calculated by the same formula as DPPH.

\section{Total Phenolic Content}

Gallic acid was taken in concentration 10, 20, 30, 40, 50 $\mathrm{mcg} / \mathrm{ml}$ and prepared in methanol and $0.5 \mathrm{ml}$ of each sample were introduced into the test tubes and mixed with $2.5 \mathrm{ml}$ of 10 -fold dilute Folin-Ciocalteu reagent and $2 \mathrm{ml}$ of $7.5 \%$ sodium carbonate. The test tubes were covered and allowed to stand for $30 \mathrm{~min}$ at room temperature before absorbance was read at $760 \mathrm{~nm}$ spectrophotometrically. First a standard curve of absorbance 
vs. concentration of gallic acid was made and then from this curve concentration of phenolic contents of the EAFNC was measured.

\section{Antimicrobial Assay ${ }^{18}$}

Antibacterial activity of EAFNC was carried out against gram positive Bacillus subtilis MTCC 5981 and gram-negative Pseudomonas aeruginosa (ATCC 9027) bacteria using well diffusion method. The lowest concentration of the sample showing complete inhibition of bacterial growth was considered as the MIC (Minimum Inhibitory Concentration).

\section{In vivo studies}

\section{Excision wound mode/ ${ }^{19,20}$}

Three groups with 6 (mice) animals in each group were anaesthetised using diethyl-ether. The back of the mice were shaved and wound of $7 \mathrm{~mm}$ radius created. The wound was left undressed into an open environment. Drugs i.e., simple gel, gel of EAFNC $(2 \% \mathrm{w} / \mathrm{w})$, the standard gel $(0.2 \% \mathrm{w} / \mathrm{w})$ Megaheal gel were administered topically for 12 days. The wound area was measured. The percentage of wound healing was calculated by the formula.

$\%$ Wound Contraction $=\frac{(\text { Initial day wound area-Specific day wound area) }}{\text { Initial day wound area }} \times 100$

\section{Incision wound mode/20,21}

Three groups with six mice in each group were anaesthetised using diethyl-ether. Their backs were shaved and an incision was made through the skin at a distance of about $1.5 \mathrm{~cm}$ from the midline of the depilated back of mice. Then parted skin was kept together and stitched with thread no. (000) at $0.5 \mathrm{~cm}$ intervals and curved needle no. 11. The wound tensile strength was measured by tensiometer on $10^{\text {th }}$ day. Tensile strength was measured by using following formula.

$$
\text { Tensile strength }=\frac{\text { Total breaking load }(\mathrm{gm})}{\text { cross }- \text { sectional area }\left(\mathrm{mm}^{2}\right)}
$$

\section{Histopathological Estimation ${ }^{22}$}

After anaesthetizing the animal, tissues were collected and fixed in neutral buffered formalin. Then it was placed in isopropyl alcohol. Then after adding xylene, paraffin was added and the tissue was mounted on the slides with Mayer's albumin solution and incubated in warm oven. Slides containing paraffin sections were deparaffinised with xylene. Then the tissue was rehydrated using isopropyl alcohol. Then again kept into running tap water for $2 \mathrm{~min}$. Then the tissue was kept into Haematoxylin stain. Then again kept into running tap water. The slide containing tissue was dipped into
1N HCl followed by Scott's water. Tissue was then immersed in Eosin stain. Slides were observed under microscope with suitable magnifications.

\section{Statistical analysis}

All the data were analysed statistically using one-way Analysis of Variance (ANOVA) followed by Dunnett's $t$-test. The data were expressed as mean \pm SEM. $p$-values less than 0.05 imply significant.

\section{RESULTS}

\section{DPPH radical scavenging activity}

EAFNC was showing significant DPPH free radical scavenging activity in comparison to ascorbic acid. Scavenging activity of EAFNC was increasing consistently with increasing concentrations (Figure 1).

\section{Nitric oxide radical scavenging activity}

EAFNC was showing significant percentage inhibition of nitric oxide as compared to the standard ascorbic acid (Figure 2).

\section{Total phenolic content}

Ethyl acetate fraction of Neolamarckia cadamba showed the presence of phenolic content which was found to be $19.31 \mathrm{mg} / \mathrm{g}$.

\section{Anti-microbial assay}

The antibacterial activities of Ethyl acetate fraction of Neolamarckia cadamba was evaluated against both grampositive and gram-negative strains. In antibacterial assay, EAFNC was found to be effective against both strains of gram positive bacteria (B. subtilis, MIC $125 \mu \mathrm{g} / \mathrm{ml}$ ) and gram-negative bacteria (P. aeruginosa, MIC $250 \mu \mathrm{g}$ / $\mathrm{ml})$.

\section{Excision Wound}

\section{Wound contraction}

In excision wound model, the wound area was measured on 1, 3, 5, 7, 9, 12 days of post-surgery. EAFNC treatment in the excision wound model resulted in a significant increase in the percentage of wound contraction from the $5^{\text {th }}$ day onwards and continued till $12^{\text {th }}$ day when compared to control group. Moreover, the wound healing activity of the standard (Megaheal gel) was found to be better than that of the EAFNC treated extract gel (Table 1 and Figure 3).

\section{Incision Wound model}

\section{Tensile strength}

In incision wound model, EAFNC treatment was showing significant increase in tensile strength on $10^{\text {th }}$ day 


\begin{tabular}{|c|c|l|c|}
\hline \multicolumn{4}{|c|}{$\begin{array}{c}\text { Table 1: Percentage wound contraction exhibited by ethyl } \\
\text { acetate fraction of gel of Neolamarckia cadamba. }\end{array}$} \\
\hline $\begin{array}{c}\text { Post } \\
\text { wound } \\
\text { day }\end{array}$ & \multicolumn{2}{|c|}{$\%$ Wound contraction (Mean \pm SEM) } \\
\cline { 2 - 4 } & Control & Standard & Treated \\
\hline 1 & $1.23 \pm 0.38$ & $2.55 \pm 0.445$ & $4.81 \pm 2.110$ \\
\hline 3 & $7.44 \pm 1.052$ & $15.55 \pm 1.061^{*}$ & $10.44 \pm 1.092$ \\
\hline 5 & $20.55 \pm 2.450$ & $35.06 \pm 1.264^{* *}$ & $30.55 \pm 1.456^{*}$ \\
\hline 7 & $32.55 \pm 1.461$ & $55.65 \pm 0.739^{* *}$ & $39.44 \pm 0.571^{* *}$ \\
\hline 9 & $49.44 \pm 0.334$ & $82.40 \pm 0.651^{* * *}$ & $57.44 \pm 1.611^{* *}$ \\
\hline 12 & $68.44 \pm 0.51$ & $95.50 \pm 0.642^{\star * *}$ & $81.33 \pm 0.574^{* * *}$ \\
\hline
\end{tabular}

Standard-Megaheal gel $(2 \% \mathrm{w} / \mathrm{w})$, Treated-ethyl acetate fraction $(2 \% \mathrm{w} / \mathrm{w})$, control gel base $(2 \% \mathrm{w} / \mathrm{w})$. Values are expressed as a mean $\pm \operatorname{SEM}(n=6)$. ${ }^{*} p<0.05,{ }^{* * *} p<0.001,{ }^{* *} p<0.01$ when compared to control)

\begin{tabular}{|c|c|}
\hline $\begin{array}{c}\text { Table 2: Estimation of tensile strength by ethyl acetate } \\
\text { fraction of }\end{array}$ \\
\hline Groups & Tensile strength $\mathbf{( g m / m m 2 )}$ \\
\hline Control & $2.968 \pm 0.355$ \\
\hline Standard & $5.022 \pm 0.052$ \\
\hline Treated & $4.645 \pm 0.135$ \\
\hline
\end{tabular}

Standard-Megaheal gel $(2 \% \mathrm{w} / \mathrm{w})$, Treated-ethyl acetate fraction $(2 \% \mathrm{w} / \mathrm{w})$, control gel base $(2 \% \mathrm{w} / \mathrm{w})$. Values are expressed as a mean $\pm \operatorname{SEM}(n=6)$.

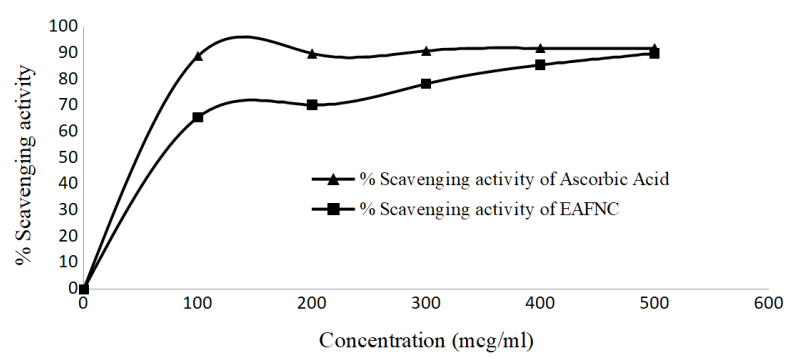

Figure 1: DPPH scavenging activity of EAFNC in comparison Ascorbic acid.

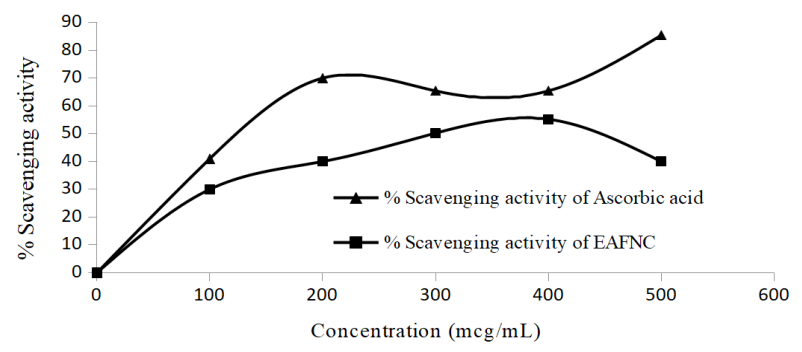

Figure 2: Nitric oxide scavenging activity of different fractions of methanolic leaves extract.

when compared to control group, which could be comparable with that of standard Megaheal gel (Table 2 and Figure 4).

\section{Histopathology of regenerated skin}

The normal tissue architecture of the mice wound on the $10^{\text {th }}$ post wounding day has been depictated (Figure

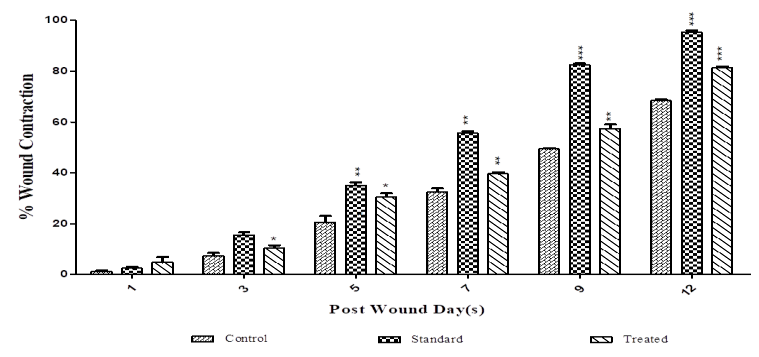

Figure 3: Percentage wound contraction of ethyl acetate fraction of gel of Neolamarckia cadamba.

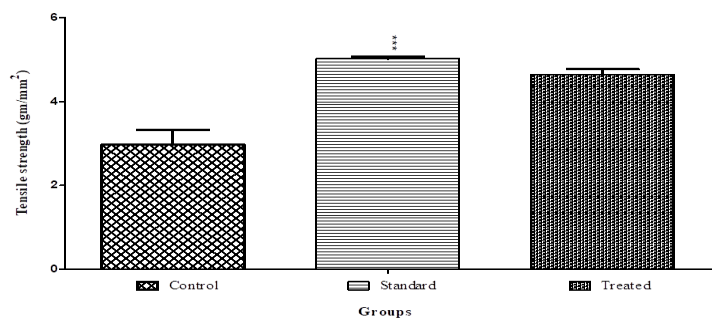

Figure 4: Estimation of tensile strength by ethyl acetate fraction of Neolamarckia cadamba.
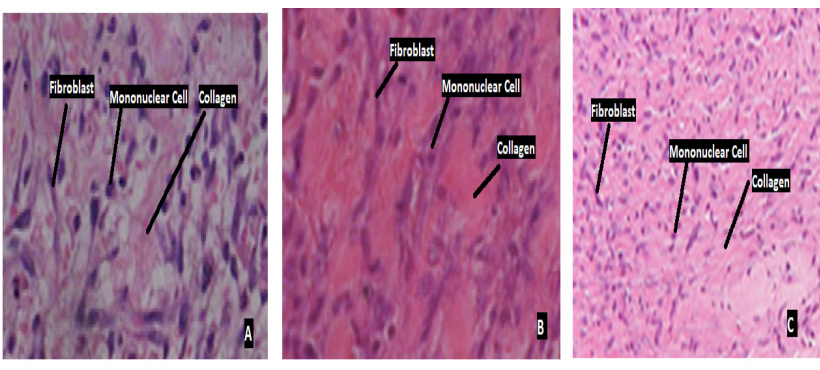

Figure 5: Histopathological view of normal and wound treated with ethyl acetate fraction, control and standard (Megaheal) of $10^{\text {th }}$ day wound of excision wound model. [(A. Control (Simple Ointment Base); B. EAFNC treated mice; C. Standard (Megaheal gel treated)]. Skin section showed hematoxylin and eosin stained epidermis and dermis.

5). It is a qualitative observational study, where control group section-A (There was Less no of mononuclear cells and less growth of collagen observed), Wound treated with ethyl fraction section-B (There was more amount of collagen growth observed but there was no significant increased in mononuclear cells) and Standard treated section-C (There was more number of mononuclear cells with more growth of collagen found). Histopathological changes were observed on wounds treated with ethyl acetate fraction topical formulation and also on the standard drug treated group. The wound showed effective neo-vascularization and significant formation of collagen after $10^{\text {th }}$ days of treatment. Epithelialization was observed to be faster in both ethyl acetate fraction and the standard groups when compared to the control group (Figure 5). 


\section{DISCUSSION}

In the present work an attempt was made to evaluate the wound healing activity of the bioactive fraction (EAFNC) of methanolic extract using in-vitro and in-vivo wound healing models. Moreover, both incisional and excisional wound models were also used for the understanding the effect of ethyl-acetate fraction on the three basic phases of wound healing process. Scientific literature also indicates the utilization of various in vitro assay formats that are employed for studying the behaviour of cell types, which are claimed to be relevant to human wound healing, with particular reference to soft tissue formation. ${ }^{25}$ From primary phytochemical studies it has been found that ethyl-acetate fraction of the plant contains polyphenol and important phytoconstituents like flavonoids which are important for wound healing activity. These flavonoids have been shown to exhibit mainly anti-inflammatory and immunomodulating activities and their beneficial effects on wounds and external and internal inflammation have also been welldocumented in the traditional medicines. ${ }^{26}$ According to reports, Staphylococcus aureus is a common bacteria, which is often known to be associated with skin infection, surgical wounds etc. ${ }^{27}$ The potential virulence factors of $S$. aureus include toxins, adhesion factors and exoenzymes that help in its colonization on host tissues, which in turn lead to serious infection. ${ }^{28}$ In the present context, in vitro antimicrobial study revealed that EAFNC also showed effective antimicrobial activity which is the supporting factor for wound healing activity. ${ }^{23}$ Drugs which inhibit free radicals generation (oxidation) is believed to increase the viability of collagen fibrils by increasing the strength of collagen fibres, preventing the cell damage and by promoting DNA synthesis. ${ }^{24}$ In antioxidant assay, EAFNC showed significant DPPH free radical scavenging and percentage inhibition of nitric oxide activity. According to report, the apparent contraction of the area of excision wounds may serve as an indicator for the progression of wound healing, which needs to be judged through the periodic assessment of the wound contraction. ${ }^{29}$ Accordingly, topical application of EAFNC gel significantly improved wound contraction. The healing process depends largely on the fibroblast regulated biosynthesis and deposition of new collagen fibres, that contribute to the improvement of the tensile strength. ${ }^{30}$ In incision wound model, EAFNC gel showed significant increase in tensile strength as compared to control group. Moreover cytotoxic activity of this plant has already been carried out by Mostafa et al. 2015, ${ }^{31}$ Which had shown moderate toxicity activity. The results of the histological study demonstrated that the wound healing and repair was accelerated following application of EAFNC gel and this was evident by the thick coverage of the wound area by an organized epidermis, along with the presence of mononuclear cells, collagen fibres, fibroblasts and some new blood vessels which indicate angiogenesis and strongly support the wound healing activity.

\section{CONCLUSION}

There are many plants used in the treatment of wounds in the tribal area but through the literature survey, it has been found that Neolamarckia cadamba is one of the plants used in the treatment of wounds. The findings suggest that this plant has potent antioxidant and free radicle scavenging activity which is attributed to the presence of polyphenols and other phytochemicals. Based on these two results, ethyl acetate fraction was chosen for wound healing activity. It also showed potent wound healing activity in both excision and incision wound models. From the result, it was concluded that similar wound contraction was in the standard and test drug which was significantly superior to control at all the periods under study.

\section{ACKNOWLEDGEMENT}

The authors are thankful to the Head, Department of Pharmaceutical Sciences and Technology, BIT Mesra, Ranchi for providing the required facilities for carrying out this project.

\section{CONFLICT OF INTEREST}

The authors declare no conflict of interest.

\section{ABBREVIATIONS}

DPPH: Diphenyl picrylhydrazyl; EAFNC: Ethyl acetate fraction of Neolamarckia cadamba; MTCC: Microbial Type Culture Collection; ATCC: American Type Culture Collection; MIC: Minimum Inhibition Concentration; SEM: Standard error Mean; ANOVA: Analysis of Variance.

\section{REFERENCES}

1. Mallefet $P$, Dwek CA. Mechanisms involved in wound healing. Biomed Scientist. 2008;52(7):609-15.

2. MacKay D, Miller L. Nutritional Support for Wound Healing. Alter Med Rev. 2003;8(4):359-77.

3. Kondo T, Idhida Y. Molecular pathology of wound healing. Foren Sci J. 2010;203(1-3):93-8.

4. Kritikar KR, Basu BD. Indian Medicinal Plants. CBS Publishers and Distributors. $2^{\text {nd }}$ ed. 2008;8:35-45.

5. Khare CP. Indian Medicinal Plants-An Illustrated Dictionary. Springer Science and Business Media LLC. $6^{\text {th }}$ ed. 2007;104-5. 
6. Malik SK, Chaudhury R, Dhariwal OP, Bhandari DC. Genetic Resources of Tropical underutilized fruits in India. National Bureau of Plant Genetic Resources. $1^{\text {st }}$ ed. 2001;25-37.

7. Duke AJ. Handbook of Nuts. CRC Press. $3^{\text {rd }}$ ed. 2001;223-56.

8. Mehta SK, Jaiprakash B, Nayeem N. Isolation and Phytochemical Investigation on leaves of Neolamarckiacadamba (Roxb.) Korth. Ann Biol Res. 2011;2(3):469-73.

9. Sahu NP, Mahto SB and Chakravarti RN. Cadambagenic acid. A new triterpenic acid from Anthocephalus cadamba Miq. Ind J Pharm. 1974; 12:284-86.

10. Muralidhar A, Babu SK, Ravishankar T, Reddana P, Latha J. Evaluation of wound healing properties of bioactive fractions from the extract of Butea monospermal Lam. Stem bark. Int J of Phytomed. 2011;3(1):41-9.

11. Harborne JB. Phytochemical Methods-A guide to modern techniques of plant analysis. Springer science and business media. $3^{\text {rd }}$ ed. 1988;4-96.

12. Shivhare UD, Jain KB, Mathur VB, Bhusari KP, Roy AA. Formulation development and evaluation of diclofenac sodium gel using water soluble polyacrylamide polymer. Dig J Nanomat Biostruct. 2009;4(2):285-90.

13. Das K, Dang R, Maachale UM. Formulation and Evaluation of a Novel herbal gel of Stevia Extract. Int J Dermatol. 2010;12(4):117-22.

14. Mishra US, Murthy PN, Pasa G, Nayak RK. Formulation and Evaluation of herbal gel containing methanolic extract of Ziziphus xylopyrus. Asian J Biomed Pharm Res. 2011;4(1):207-18.

15. Goyal S, Ramchandani U, Shrivastava SK, Dubey PK. Novel Antiinflammatory topical Herbal Gels containing Withania somnifera and Boswellia serrate. International Journal of Pharmaceutical and Biological Archives. 2011;2(4):1087-94.

16. Royera M, Dioufb PN, Stevanovic T. Polyphenol contents and radical scavenging capacities of red maple Acer rubrum L. extracts. Food Chem Toxicol. 2011;49(9): 2180-8.

17. Somsak N, Kwanchai R, Sushitr T. Anti-inflammatory, analgesic and wound healing activities of leaves of Memecylon edule Roxb. J Ethnopharmacol. 2009;121(2):278-81.

18. Subhashini N, Thangathirupathi A, Lavanya N. Antioxidant activity of Trigonella foenum Graecum using various in vitro and ex vivo models. Int $\mathrm{J}$ Phar and Pharm Sci. 2011;3(2):96-102.
19. Morton JJ, Malone MH. Evaluation of vulnerary activity by an open wound procedure in rats. Arch Int Pharmacodyn Ther. 1972;196(1):117-26.

20. Nema A, Gupta N, Jain UK. Evaluation of wound healing activity of Tinospora cordifolia Wild. Der Pharm Sinica. 2012;3(1):126-30.

21. Ehrlich HP, Hunt TK. Effects of Cortisone and vitamin A on wound healing Ann Surg. 1968;167(3):324-8.

22. Bang RL, Dashti H. Keloid hypertrophic scars: Trace element alteration. J Nutrition. 1995;11(5 Suppl):527.

23. Shenoy M. Animal biotechnology, Laxmi publication. $1^{\text {st }}$ ed. 2007;138-44.

24. Panda P, Tripathy $G$. Wound healing activity of aqueous and methanolic bark extract of Veronicas arborea in Wistar rats. Nat Prod Rad. 2009;8(1):6-11.

25. Mehta SK, Mukharjee S, Jaiprakash B. Anti-inflammatory activity of the methanolic extract of Buchanania lanzan leaves by carrageenan-induced rat paw edema method. Int J Pharm Sci Rev and Res. 2011;6(2):144-45.

26. Galati EM, Mondello MR, Monforte MT, Galluzzo M, Miceli N, Tripodo MM. Effect of Opuntia ficus-indica (L.) Mill. cladodes in the wound healing process. J Prof Asso Cact Dev. 2003;5:1-16.

27. Sajna AM, Kuruvilla M, Shenoy S, Bhat GK. Methicillin resistant Staphylococcus aureus (MRSA) in skin isolates from hospital acquired infections. Indian J Dermatol Venereol Leprol. 1999;65(5):222-4.

28. Arvidson S. Fischetti VA, Novick RP, Ferretti JJ, Portnoy DA, Rood JI. Extra cellular enzymes. In: Eds. Gram-Positive Pathogens. Am Soc Micro. $2000 ; 735$.

29. Suguna L, Singh S, Sivakumar P, Sampath P, Chandrakasan G. Influence of Terminalia chebula on dermal wound healing in rats. Phytother Res. 2002;16(3):227-31.

30. McFarlin K, Gao X, Liu YB, Dulchavsky DS, Kwon D, Arbab AS, et al. Bone marrow-derived mesenchymal stromal cells accelerate wound healing in the rat. Wound Repair Regen. 2006;14:471-8.

31. Mostafa KATM, Kazi AAC, Masud R, Azharul I, Estekhar AK, Areeful H, et al. "Study of Cytotoxic, Thrombolytic and Anthelmintic Activity of Extract of Neolamarckia cadamba (Roxb.) Leave". European J Med Plants. 2015;10(2):1-9.

\section{SUMMARY}

In India medicines based on herbal origin has been the basis of treatment and cure of various diseases. So, a large number of plants species are used for this purpose. Among all those plants, one such plant is Neolamarckia cadamba and it belongs to the family Rubiaceae. Neolamarckia cadamba leaves had been used by the tribal people for the treatment of wounds.

Hence, the present study was aimed to explore the wound healing potential of leaves of Neolamarckia cadamba using incision and excision wound models. Leaves of the plant were dried and extracted by using various solvents. From the preliminary phytochemical studies of methanolic leaves extract of Neolamarckia cadamba was showing better presence of polyphenol and important phytoconstituents which are responsible for wound healing activity. Ethyl acetate fraction of methanolic leaves extract of Neolamarckia cadamba (EAFNC) was used for gel preparation after successful screening of in vitro test. Ethyl acetate fraction of the methanolic extract also showed antimicrobial activity which is the supporting factor for wound healing activity. The two in-vivo wound models (incision and excision) have been chosen for the study to access the effect of ethyl acetate fraction of methanolic extract of Neolamarckia cadamba (Roxb.) on wound healing. In both wound models, Ethyl acetate fraction (gel formulation) was showing significant increase in contraction of wound as well as increase in tensile strength as compared with control and the significant result of the (EAFNC) study was also comparable with that of standard drug (Mega heal gel). In Histopathology study, ethyl acetate fraction treated skin showed the presence of mononuclear cells, collagen fibres, fibroblasts and some new blood vessels which indicate angiogenesis and strongly support the wound healing activity. 


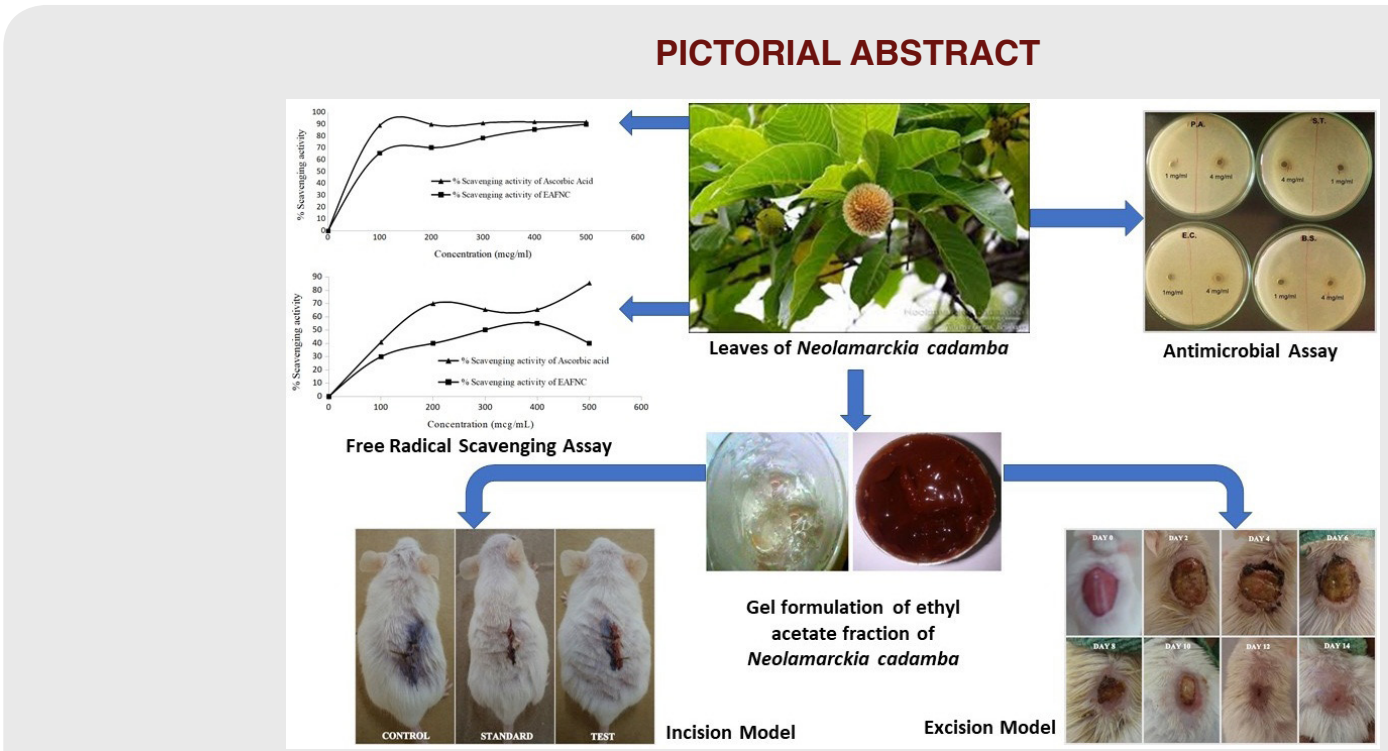

\section{ABOUT AUTHORS}

Ashok Pattnaik: He did his Ph.D from Department of Pharmaceutical Sciences and Technology, Birla Institute of Technology, Mesra, Ranchi. Currently, he is working as an Associate Professor at the Department of Pharmaceutical Science and Technology, BIT Mesra. The major focus of Dr. Ashok Pattnaik is on understanding the molecular mechanism and target pathway of obesity and wound healing activity and to explore Antiobesity activity of various synthetic and Medicinal Plants in different animal model. He has more than 22 nos research publication in his research credential.

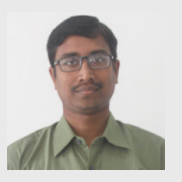

Manik Ghosh: He had his Ph.D from Department of Pharmaceutical Sciences and Technology, Birla Institute of Technology, Mesra, Ranchi. Currently, he is working as an Assistant Professor at the Department of Pharmaceutical Science an Technology, BIT Mesra. He is actively involved in the following research fields: Isolation and Characterization of Biological active compounds (antiviral/ anticancer) from natural sources; analytical and bio-analytical chemistry; In silico Drug Designing. His research activity is proved by numerous noteworthy publications on international journals.

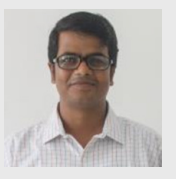

Kishanta Kumar Pradhan: He is working as an Assistant Professor at the Department of Pharmaceutical Sciences and Technology, BIT Mesra. He is actively involved in the following research fields: Natural Product Chemistry and Analytical Research. He has more than 22 nos of research publications in his research credential.

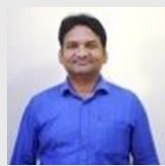

Chanchal Kumar Mishra: He is working as an Assistant Professor at the Department Polytechnic, BIT Mesra, Ranchi. He is actively involved in the following research fields: Phytochemistry and Pharmacology.

Shruti Nayan: She did her M.Pharm from Department of Pharmaceutical Sciences and Technology, BIT Mesra, Ranchi, (2016).

Divya Priyadarshini: She did her M.Pharm from Department of Pharmaceutical Sciences and Technology, BIT Mesra, Ranchi, (2019).

Cite this article: Nayan S, Mishra CK, Priyadarshini D, Pradhan KK, Ghosh M, Pattnaik A. Wound Healing Activity of Gel Formulated Leaves Extract of Neolamarckia cadamba (Roxb) Bosser. Indian J of Pharmaceutical Education and Research. 2019;53(3 Suppl 2):s416-s422. 